\title{
Homosexuality in the Context of the Evolution Theory
}

\author{
Constantinos Maritsas \\ Sofia University “Sv. Kliment Ohridski”, Sofia, Bulgaria
}

\begin{abstract}
The purpose of the paper is to show violence as the integral property of any live being. One of the aims of civilization is to provide a controlled portion of violence to the community members. If the portions are too small then uncontrolled violence appears in different forms of criminality and self-destruction. In countries without virtual violence the terrorism and "suicide" bombers are born. For the male the aim of violence is a feeling of victory. In the nature only the winner has the right to reproduction. In a civilized society each male has the right to reproduction and the necessity to feel himself as a winner. Survival means right for reproduction. Civilization has turned the bite between men into a kiss between men (men winner) and women (men defeated), the kick between men - into a caress between men (men winner) and women (men defeated) and, finally, the violence between men into love/eros between men (men winner) and women (men vanquished) and violence between men into homosexuality/eros between men winner and men vanquished. In the civilization, the male is winner and the female simulates the defeated male, homo or animals. We can define eros as a substitute of violence in civilization like the metamorphose of violence.
\end{abstract}

Keywords: homosexuality, eros, love, evolution theory, violence

\section{Introduction: Civilization as the Survival of the Weak: Rethinking Evolutionary Theory in Civilizational Context}

Till now, all definitions of civilization which we have are anthropocentric and they, as a rule, are considered as well confirmed stereotypes in different fields of science and humanities. The author's concept is largely influenced by Darwin's principle of natural selection, which is to be reconsidered and rethought and which operates always and everywhere, if we only determine its criteria and scope. Man (referring primarily to male), the weak and helpless against natural forces, was subject to destruction for two reasons: He was an easy prey to predators, and males died in the inner species battle. Consequently, male was doomed to extinction. The only solution was to end the violent inner species struggle for supremacy and replace it with other selection criteria. The first selection criteria were found in nature. We suppose that they have been song, beauty, and gifts. Man had to adapt to the new "civilizational" criteria. The author's hypothesis is based on two facts. Firstly, even today "song, beauty, and gifts" are expressions of love or preference of men (males) regardless of the level of civilization, and secondly, it is the same with animals. But abolishing the intraspecific competition, male got biologically weak and he became an easier prey for animals. Then he made the second step. He terminated the coercive fighting with animals having replaced it with dance. After totally eliminating violence as a criterion, woman began to select on the grounds of language (music, word), beauty (decoration, fashion, art) and gifts (wealth, property). Man has gone from the natural (subconscious) selection to the acquired (conscious) 
selection, that is, man is not a result of natural selection.

So we have the final no anthropocentric definition of civilization: "Civilization is the survival of the weak" (Maritsas, 2003, p. 93).

\section{Civilization and Men (Male)}

Civilization mixed up the roles of men and women. With animals and the primitive tribes, the male specimen, the man, was who swaggers, and was selected by the female one, the woman. The man went hunting and fights. In civilization, man began to be chosen upon non-natural criteria: language, attractiveness, ownership. The weak man survived and reproduced. Gradually, the man began also to select and the woman was aiming to make herself look attractive for the man, which was a fact opposed to the natural one where the man had to convince the woman in his own value. There was a discrepancy between the conscious and the subconscious. The roles were mixed up. The woman played the role of the vanquished man, and the man - that of the woman selected by nature without fighting.

\section{Civilization and Women (Female)}

Women have been the creator of civilization, and at the same time, they have been its victims.

According to the natural selection the woman, being already selected, decided by the man - "the hero", with whom she would have children. The heroes were only men, there was no a woman hero. Yet, in today's epoch women are not only provoked to select after acquired criteria, but also provoked to be selected, i.e., to fight for the conquest of man. The conscious selection and the necessity of selection developed "consciousness", the acquired selection was limited to the "subconscious", and the natural selection moved to the "non-realized".

The woman was forced to become a man. Not an ordinary man, but a vanquished one.

The man winner (man) used violence towards the vanquished man (woman). The male individuals was generally violent towards women. They restricted women in order to show up their manliness before the other men.

With elimination of violence, man lost his way to excitement. Through the dance (civilization), the woman selected the man who afterwards she had to make fertilize her. Thus, the woman was forced to accept the role of the vanquished man. Suddenly, the society began to consist of men winners (men) and vanquished men (women). The woman became subordinate, obliging.

The goal of the woman was to preserve the species, i.e., the selection and creation of children with the man (the hero) was suppressed. The woman nowadays is provoked to think as a (vanquished) man. The woman, the goddess was lowered to an ordinary mortal. The man is afraid and does not want a woman victor, educated and rich. The woman is not interested in anything connected with "civilization", she is only interested in preserving the species and what would follow as a result. It is clear that most women who make a professional carrier, in fact hate the job they devote their whole day to. And women, who are forced to combine their job and the household are getting so tired that they get to a point, when they neglect their clothing, they stop smiling and start argue with their colleagues and bosses, even forget to put lipstick in the morning. For all they are forced to do they blame their husbands being unable to support the family. At the same time the working women earn more than most men. The woman - man is better than the man himself, because in what she does she experiences the motherhood, the child, so the woman professional has the attitude towards work like the mother who will do her best for the survival of the job, of the professional success, or she acts as a man much 
better than men. The new type of a woman seemingly (consciously) has nothing to do with the traditional housewife or wife. The woman feminist works everywhere. The vainglorious women hate household, run in the gyms, drink and smoke like men. The most recent studies have showed that most women have love relations with more than one man. Usually mothers keep in secret about the real father of their children. Scientists explain this behavior with the tendency of women to have children from "good" men, i.e., with men heroes. Therefore the selection works with the woman who is forced to select a husband (or to be selected by the husband) after acquired criteria but the father of the child is selected after other, more natural criteria. That is to say, the woman can select for a husband an old and rich man, or to be selected by him because she is beautiful but she will choose for the father of her child a young, handsome and smart man.

In civilization, man began to select and the woman to spruce up to attract the man. Sprucing up is to represent the woman as a vanquished man and to leave in him the impression that she is the victor and she teases him. That is why woman colors her lips and nails red (blood), the eyes blue or green (marks from hits), wears chains on her arms, the neck, the legs (a chained slave) (see Table 1).

Table 1

The Man Swaggers as a Victor and the Woman as a Vanquished/Man!

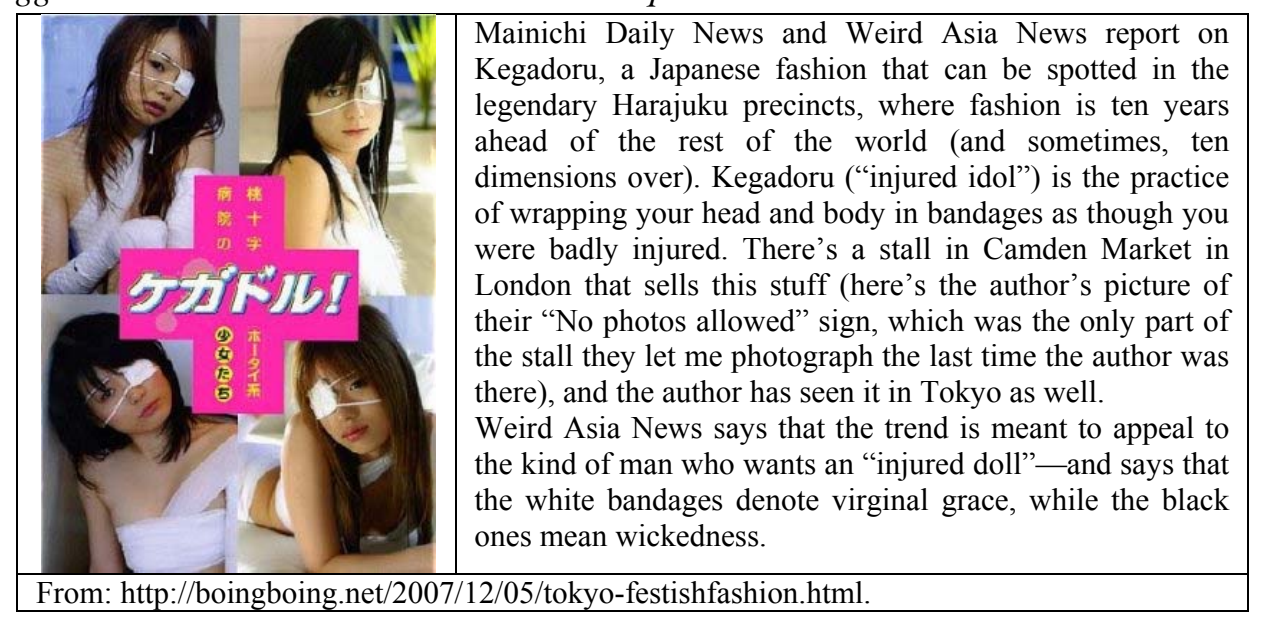

\section{Eros as Metamorphose of Violence}

Therefore there is still no answer to the question "What is eros?", although we all claim that man makes love/eros! What is more, he is the only (?) animal that makes love/eros and he does it face to face (see Figure 1).

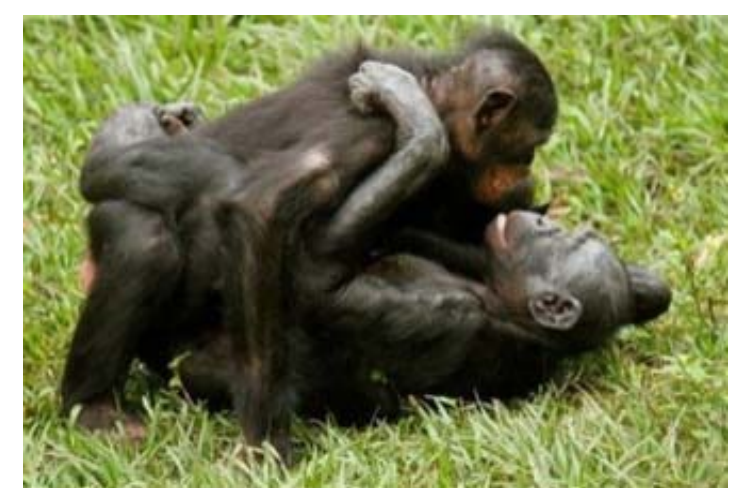

Figure 1. Bonobo makes love/eros face to face. 
What could provoke interest here is the striving for correlation of eros and death (not life):

(a) "The higher relation between Eros and Death is still in full darkness" (Marcuse, 1981, p. 36).

(b) "Two contrary instincts develop from the common nature of the instincts. The life instincts (Eros) prevail over the death instincts" (Marcuse, 1981, p. 35).

(c) "These arch for a common origin of both significant instincts (meaning Eros and Death - my note) cannot be concealed anymore" (Marcuse, 1981, p. 37).

But why should it be "concealed"? Is it so bad or dangerous if eros and death have a common origin? There is such idealization of eros that everybody shivers even at the thought of dealing with its origin.

How is it possible to speak in different words about eros? Biologists get used to refer to the word "eros" as to something that comes from the romantic civilized concept without any specific scientific interest and they do not admit the simple fact that eros is, at least, a biological fact. (Morris, 1970, p. 10)

Eros is not a "biological phenomenon" neither, of course, is "a result of a romantic concept without any scientific interest". It is not "a biological phenomenon" because only man among dozens of animal species makes eros. It is not "a result of a romantic concept without any scientific interest" because the formulation itself has no scientific base.

That is why, even nowadays, violence is an excitement and it pursues the eros/the love. The man wants to see the vanquished enemy that is the woman: "The continuous staring from nearby is noticed not only in erotic situations but also in threatening ones" (Morris, 2000, p. 73). The red color, the color of the enemy's blood excites him. Scratches, bites, kicks according to Kama Sutra are extremely exciting.

We can define Eros as a substitute of Violence in civilization like the delight of violence in relation to reproduction.

\section{Love and Homosexuality (Eros) as Metamorphose of Violence}

Civilization has turned the biting into kiss, the kick into caress and Violence into Eros. The bite between men transformed into a kiss between men and women, and the kick between men into a caress between men and women.

Pseudo attack. Adults exchange many knocks in the kin, ruffle of hairs, bits on the ears, pushing, drawing, grips, and bites, which while being a manifestation of aggression is done so tenderly and not hurting. ... From time to time they are the only way a man can have a close body contact to another, for example the father and the son-because he knows that a patent tender move will put him in an awkward position. (Morris, 2000, p. 101)

"In the striving for permanent arming himself against the everyday attacks man often comes to the situation where each contact is defined as odious. To touch or to be touched means to hurt or to be hurt" (Morris, 1972, p. 323). Eros became pride for the man and shame for the woman. Eros is victory for the man, while for the woman it is a defeat. So was generated the (male) homosexuality that does not exist with animals, no civilized animals. "Civilization has turned the biting into kiss, the kick into caress and Violence into Homosexuality-Eros. The bite between men transformed into a kiss between men, and the kick between men-into a caress between men". "They indulge (meaning bonobo - the author's note) in sex at the slightest teasing or the most passing challenge and with any possible way containing even a French or a homosexual element and the females are receptive for long periods of time" (Kafedzopoulos, 1999, p. 119). Man is in search of violence - eros (love and homosexuality). That is why violence today is pursued by sexual abuse, for 
example, instead of "I will break your head" the threat is "f... you" or "f... your (some female relative)". "If you see two people making love you will think they are fighting" (Osho, 2002, p. 126). Nowadays, through eros (love and homosexuality) man does not experience death but only its substitute. Everyone who experiences it reproduces, for example stewardesses, nurses, but also Roma (gypsies), people in the countries with high death rate, etc.. The movies with violence provide the portions of violence to people who need it. In sports, everyone identifies with the winner in order to obtain the reproduction right.

\section{Conclusion}

In this paper, the author showed that eros (love and homosexuality) can be explained on the ground of Darwin's theory. But it is necessary to define the concept of civilization and its selection criteria. On the basis of the Darwinian Theory, the author defines civilization as "survival of the weak" (Maritsas, 2007, p. 141).

The author has shown in this paper that love and homosexuality have been created unconsciously by the weak male. The aim was for the weak male, the creator of civilization, to survive by means of the eros as metamorphose of violence. Survival means right for reproduction. Civilization has turned the violence between men once into love-eros between men (men winner) and women (men vanquished) and, second, into homosexuality-eros between men winner and men vanquished.

\section{References}

Kafetzopoulos, E. (1999). The sexual ape. Athens: Katoptro.

Marcuse, H. (1981). Eros \& civilization. Athens: Kalvos.

Maritsas, C. (2003). Civilization and natural selection. Athens: Arsenidis.

Maritsas, C. (2007). Civilization and natural selection 2. Sofia: University Press "Sv. Kliment Ohridski".

Morris, D. (1970). The naked ape. Athens: Kedros.

Morris, D. (1972). The significance of contact. Athens: ORORA.

Morris, D. (2000). Human observation-Human behavior. Athens: Arsenidis.

Osho. (2002). Tantra-Spirituality and sex, Athens: REMBEL. 